\title{
Tertiary Students' Socialization of Entrepreneurial Behavior
}

\author{
Chun-Mei Chou ${ }^{*}$, Chien-Hua Shen ${ }^{2}$, His-Chi Hsiao3, Su-Chang Chen4, Hui-Tzu Chang5, \\ Jing-Yi Chen6 \\ ${ }^{1}$ Institute of Vocational and Technological Education, National Yunlin University of Science and Technology, \\ Yunlin, Taiwan \\ ${ }^{2}$ Department of Business Administration, Transworld Institute of Technology, Yunlin, Taiwan \\ ${ }^{3}$ Department of Business Administration, Cheng Shin University, Kaohsiung, Taiwan \\ ${ }^{4}$ Department of Marketing and Logistics and Management, National Penghu University of Science and \\ Technology, Taiwan \\ ${ }^{5}$ Institute of Education, National Chiao Tung University, Taiwan \\ ${ }^{6}$ Department of Information Management, National Yunlin University of Science and Technology, Taiwan \\ Email: ${ }^{*}$ choucm@yuntech.edu.tw, shen17@ms51.hinet.net
}

Received May 2014

\begin{abstract}
This study examines 674 tertiary education students' socialization of entrepreneurial behavior and its influencing factors. The results show that students' internship experience (IE) has a significant direct effect on socialization of entrepreneurial behaviors (SEB), and entrepreneurial selfefficacy (ESE) has a significant effect on SEB through IE. The influence pattern and empirical data of ESE and IE on SEB has a good fit.
\end{abstract}

Keywords

Internship Experience, Socialization of Entrepreneurial Behaviors, Entrepreneurial Self-Efficacy

\section{Introduction}

Entrepreneurial education plays the role of helping to reduce the unemployment rate in a country [1] [2]. Some research found that students' experiences in entrepreneurial education and entrepreneurial self-efficacy have provided them with chances to learn new entrepreneurial skills, which may be helpful for their future entrepreneurial endeavours [1] [3] [4]. Enterprise educational learning could influence the perceived desirability of starting a business [5] [6].

Research found that entrepreneurial education can be a powerful instrument towards achieving business excellence [7] [8]. It should be the hub of activities, bringing together and matching various disciplines in every combination possible. The number of colleges and universities that offer courses related to entrepreneurship has grown. In the midst of this huge expansion the challenge remains for complete academic training for entrepreneurship. While it can be argued that some success has been attained in the current state of entrepreneurial education, critical challenges lie ahead [9] [10]. Obschonka et al. provided empirical evidence regarding the expo-

\footnotetext{
*Corresponding author.
} 
sure to entrepreneurial education as an additional exposure variable in entrepreneurial intentions [11].

Some research found students' socialization of entrepreneurial behaviour, internship experience and entrepreneurial self-efficacy have provided them with chances to learn new entrepreneurship skills, which may be helpful for their future employability and entrepreneurial skills [12]-[14].

From a socialization theory point of view, the entrepreneurial self-efficacy (ESE) becoming socialization of entrepreneurial behaviours (SEB) has been depicted as actively entrepreneurial ambition [9] [10] [15]. The availability of a validated instrument to measure internship norm, internship attitude and entrepreneurial intention towards SEB could be of much help [11] [12] [16].

Internship experience was defined as the attitude towards internship attitude of internship goal, external employability and labor market characteristics [8] [9]. Therefore, high IE of students has actually indicates towards high self-perceived entrepreneurial behavior and learning effect [17]-[19]. Socialization of entrepreneurial behaviors and given feedback from the employability learning results in which entrepreneurial intention is raised. Research suggests that entrepreneurial self-efficacy (ESE) is important to affect socialization of entrepreneurial behavior [10] [14] [20]. It is positively related to students' internship norms, internship attitude and entrepreneurial intention. It is suggested that the concept of internship experience, derived from socialization theory plays an important role in the development of IE and SEB [15] [16] [21] [22].

The paper, Analysis of factors in tertiary education students' perceived ESE and SEB, using IE as a mediator variable, discussed the variables which may influence tertiary education student's ECI and found the relationships among the variables. The purposes of this study are to address the 4 following issues.

1. There is no significant correlation between tertiary education students' ESE and SEB.

2. There is no significant correlation between tertiary education students' perceived ESE and IE.

3. There is no significant correlation between tertiary education students' IE and SEB.

4. Influence models of tertiary education students' ESE, IE, and SEB fit the data collected by this study.

\section{Methodology}

\subsection{Subjects}

This study treats 674 tertiary education students from tertiary education schools as the population, and adopts random sampling and cluster sampling for survey.

\subsection{Research Tools}

The research tool is a "Questionnaire of Factors Which Influence Tertiary Education Students' Socialization of Entrepreneurial Behavior”. The questionnaire includes Internship experience Scale, Entrepreneurial self-efficacy Scale and Socialization of entrepreneurial behavior Scale [4] [15] [16] [20]. The "Questionnaire of Factors Which Influence Tertiary Education Students” SEB was reviewed by three experts for subject contents' suitability to ensure the scale's expert validation. Five tertiary education students were invited to answer the questionnaire to enhance the validity of the scale's contents. In addition, six tertiary education schools were selected for a pre-test, and 122 students were selected as the pre-test objects in total. The scales used in this study are in self-assessment form, and a Likert 5-point scale is used as the scoring method. There are five levels of choices from "agree" to "do not agree"; five equal portions of 5, 4, 3, 2 and 1 are distinguished according to the extent of agreement, and 5 points, 4 points, 3 points, 2 points and 1 point are given in this order. The higher the score an individual receives, the larger extent of agreement the individual has. The scales' factors, number of questions reliability and validity are shown in Table 1.

\subsection{Data Analysis}

In processing the survey data used in this study, the collected questionnaires were coded, and Statistical Package for Social Science (SPSS version 12.0) and linear structural analysis (LISREL version 8.5) were used to verify the correlation among the factors of IE, ESE and SEB variables and their effects in order to achieve the purpose of this study.

\section{Results}

The empirical results of tertiary education students' SEB are shown in Figure 1, and are analyzed as follows: 
Table 1. An overview of factors, number of questions, reliability and validity for tertiary education students' IE, ESE and SEB scale.

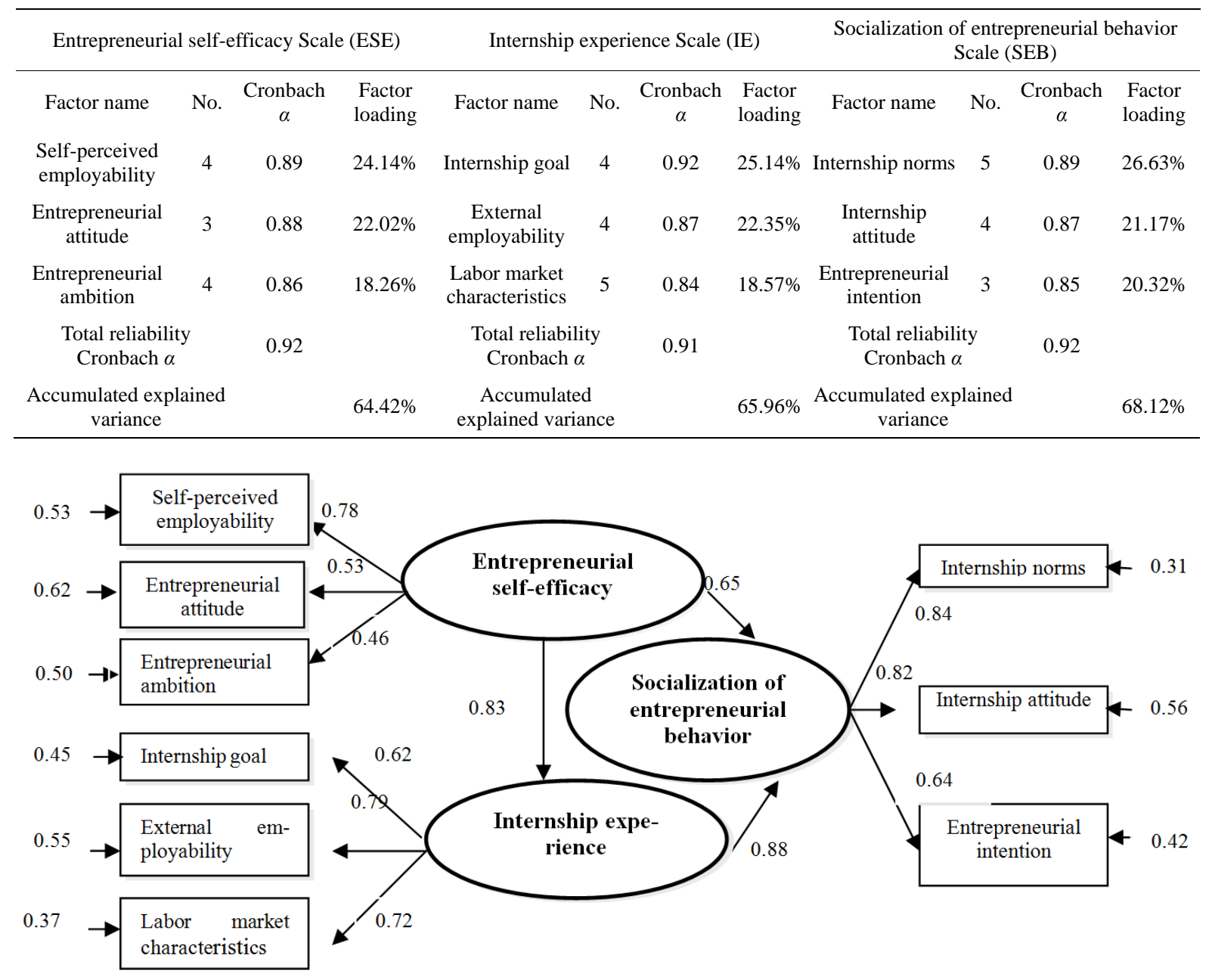

Figure 1. Path of technical and vocation school students' SEB.

The estimated value of the direct affecting parameter between IE and ESE is $0.83(t=6.71, p<0.05)$. This means that IE has a significant effect on ESE. The estimated value of the direct affecting parameter between IE and SEB is $0.65(t=5.18, p>0.05)$. This means that IE does not necessarily have a significant effect on ECI. The estimated value of the direct affecting parameter between ESE and SEB is $0.88(t=6.23$, $p<0.05)$. This means that ESE has a significant effect on SEB. In summary, in this study of tertiary education students' SEB and its influence pattern, IE has a significant effect on ESE, but does not have a significant effect on SEB, and ESE has a significant effect on SEB.

\section{Conclusions}

Students' IE has a significant direct effect on SEB, and ESE has a significant effect on SEB through IE. The influence pattern and empirical data of ESE and IE on SEB has a good fit. The influence effects of IE, ESE and SEB shows that for tertiary education students, the influence of ESE on SEB comes mainly through their awareness of IE. In addition, IE has a direct and significant effect on SEB. From the influence of IE, ESE and SEB, we can clearly see that compared with ESE, IE has a greater influence on SEB [4] [5] [17] [20].

Regarding the test results, according to the goodness of fit test standard by Hair et al, the model in this study has a good overall fit [15] [18]. In the absolute fitness and incremental fitness tests, all indices meet the standard, and have the best fit. Most of the parsimonious fitness indices meet the test standard, and have a good fit. Over- 
all, in the SEB and its influence model established in the study based on theories, both the model and the data have a good fit, and in the parameter estimation most of the estimated values are significant. This shows that all the indices of latent variables have their importance, and only the parameter value of ESE on ECI is low. Overall, the empirical data have a good explanatory power. Students' ESE influences IE and "Self-perceived employability” is an important factor which influences ESE. Students' ESE influences SEB, "Self-perceived employability" and "Entrepreneurial attitude" are important factors which influence ECI [6] [17] [19] [20].

The results show that among all latent variables in the model, the direct influence of ESE on SEB is not significant, indicating that the assumed influence of ESE on students' SEB needs further testing; this is something worthy of a more in-depth study and validation in the future. Based on test results, although the overall result is acceptable, the model consistency level is not entirely satisfactory, and its Internship experience has a relatively low explanatory power for ECI. The possible reasons are:

- The measurement error variance of the three main variables in the model is too large. Although in the course of the investigation in this study each step was made following reasonable procedures, in a sample survey there are a survey bias and restrictions on the study objects in answering the questionnaire. These can result in a bias between the survey data and the actual situation [13] [19] [21].

- The influence of test indices and method. Currently in the verifying calculation of structural equations, the index value is subject to the sample size, and sometimes the index value may influence each other. When the index is far greater than or much lower than the standard value, the judgment is more accurate; when the index is close to the standard value, we then need to consider the possible influence from the error.

- The missing scope of variables. Although a complete research model was tried to be established in this study based on past researches and theories, there has been little domestic research on the topic of students' ECI.

\section{Implication}

There may be undetected factors which resulted in a low explanatory power, and there are other variables which have not been identified [15] [16] [23] [24]. Regarding this model's test results, perhaps in the future a further study can be conducted to find the variables either missing in the theories or can be further added or deleted, or more comprehensive empirical data can be collected for testing to improve the consistency between this model and empirical data.

\section{Acknowledgments}

This paper was written while the authors were supported by a grant from the National Science Council, Republic of China (NSC 102-2511-S-224 -001 -MY3)

\section{References}

[1] Culbertson, S.S., Smith, M.R. and Leiva, P.I. (2011) Enhancing Entrepreneurship: The Role of Goal Orientation and Self-Efficacy. Journal of Career Assessment, 19, 115-129. http://dx.doi.org/10.1177/1069072710385543

[2] Boore, J. and Porter, S. (2011) Education for Entrepreneurship in Nursing. Nurse Education Today, 31, $184-91$. http://dx.doi.org/10.1016/j.nedt.2010.05.016

[3] Chou, C.M., Shen, C.H., Hsiao, H.C., Chang, H.T., Lee, W.H., Chen, S.C., Chen, C.P. and Chang, J.C. (2011) The Influencing Factors of Student Teachers’ Entrepreneurial Learning Behavior. 2011 Fourth International Joint Conference on Computational Sciences and Optimization (CSO 2011), Yunnan.

[4] Chen, J.Y. and Liu, Y.C. (2011) A Study on the Determinants of Regional Distribution of New Firms in Service Industry for Taiwan. Journal of Entrepreneurship Research, 6, 1-32.

[5] Bienkowska, D. and Klofsten, M. (2012) Creating Entrepreneur Networks: Academic Entrepreneurship, Mobility and Collaboration during PhD Education. Higher Education, 64, 207-222. http://dx.doi.org/10.1007/s10734-011-9488-x

[6] Lanero, A., Vázquez, J.L., Gutiérrez, P. and García, M.P. (2011) The Impact of Entrepreneurship Education in European Universities: An Intention-Based Approach Analyzed in the Spanish Area. International Review Public Nonprofit Marking, 8, 111-130. http://dx.doi.org/10.1007/s12208-011-0067-8

[7] Leitch, C. (2007) An Action Research Approach to Entrepreneurship. In: Neergaard, H. and Ulhoi, J.P., Eds., Handbook of Qualitative Research Methods in Entrepreneurship, Edward Elgar, Massachusetts, 144-168. http://dx.doi.org/10.4337/9781847204387.00015

[8] Liñán, F., Rodríguez-Cohard, J.C., Rueda-Cantuche, J.M. and Rueda-Cantuche, J.M. (2011) Factors Affecting Entre- 
preneurial Intention Levels: A Role for Education. International Entrepreneurship and Management Journal, 7, 195218. http://dx.doi.org/10.1007/s11365-010-0154-z

[9] Liao, W.C. and Lee, P.S. (2011) The Functions of Technology Industry High-Level Managers of SMEs in Taiwan. Quarterly of SMEs Development, 20, 1-22.

[10] Mansor, M. and Othman, N. (2011) Consulting-Based Entrepreneurship Education in Malaysian Higher Education Iistitutions. 2011 International Conference on Social Science and Humanity, Singapore, Vol. 5, 351-355.

[11] Obschonka, M., Silbereisen, R.K., Schmitt-Rodermund, E. and Stuetzer, M. (2011) Nascent Entrepreneurship and the Developing Individual: Early Entrepreneurial Competence in Adolescence and Venture Creation Success during the Career. Journal of Vocational Behavior, 79, 121-133. http://dx.doi.org/10.1016/j.jvb.2010.12.005

[12] Nejad, B.A. and Abbaszadeh, M.M.S. (2012) Study of the Entrepreneurship in Universities as Learning Organization Based on Senge Model. International Education Studies, 5, 67-77.

[13] Mars, M.M. and Garrison, S. (2009) Socially-Oriented Ventures and Traditional Entrepreneurship Education Models: A Case Review. Journal of Education for Business, 85, 209-296.

[14] McGee, J.E., Peterson, M., Mueller, S.L. and Sequeira, J.M. (2009) Entrepreneurial Computer self-Efficacy: Refining the Measure. Entrepreneurship Theory and Practice, l, 965-988. http://dx.doi.org/10.1111/j.1540-6520.2009.00304.x

[15] Obschonk, M., Silbereisen, R.K. and Schmitt-Rodermund, E. (2010) Entrepreneurial Intention as developmental Outcome. Journal of Vocational Behavior, 77, 63-72. http://dx.doi.org/10.1016/j.jvb.2010.02.008

[16] Todorovic, Z.W., McNaughton, R.B. and Guild, P. (2011) ENTRE-U: An Entrepreneurial Orientation Scale for Universities. Technovation, 31,128-137. http://dx.doi.org/10.1016/j.technovation.2010.10.009

[17] Wilson, F., Kickul, J. and Marlino, D. (2007) Gender, Entrepreneurial Self-Efficacy, and Entrepreneurial Career Intentions: Implications for Entrepreneurship Education. Entrepreneurial Theory and Practice, 31, 387-406.

[18] Yemini, M. and Haddad, J. (2010) Engineer-Entrepreneur: Combining Technical Knowledge with Entrepreneurship Education-The Israeli Case Study. International Journal of Engineering Education, 26, 1220-229.

[19] Kumara, P.A.P.S. (2012) Undergraduates’ Intention towards Entrepreneurship: Empirical Evidence from Sri Lanka. Journal of Enterprising Culture, 20, 105-118. http://dx.doi.org/10.1142/S0218495812500057

[20] Lee, L.,Wong, P.K., Foo, M.D. and Leung, A. (2011)Entrepreneurial Intentions: The Influence of Organizational and Individual Factors. Journal of Business Venturing, 26, 124-136. http://dx.doi.org/10.1016/j.jbusvent.2009.04.003

[21] Ma'atoofi, A.R. and Tajeddini, K. (2010) The Effect of Entrepreneurship Orientation on Learning Orientation and Innovation: A Study of Small-Sized Business Firms in Iran. International Journal of Trade, Economics and Finance, 1, 254-260. http://dx.doi.org/10.7763/IJTEF.2010.V1.46

[22] Madhoushi, M., Sadati, A., Delavari, H., Mehdivand, M. and Mihandost, R. (2011) Entrepreneurial Orientation and Innovation Performance: The Mediating Role of Knowledge Management. Asian Journal of Business Management, 3, 310-316.

[23] Memili E., Eddleston K.A., Kellermanns, F.W., Zellweger, T.M. and Barnett, T. (2010) The Critical Path to Family Firm Success through Entrepreneurial Risk Taking and Image. Journal of Family Business Strategy, 1, 200-209. http://dx.doi.org/10.1016/j.jfbs.2010.10.005

[24] Oosterbeek, H., van Praag, M. and Ijsselstein, A. (2010) The Impact of Entrepreneurship Education on Entrepreneurship Skills and Motivation. European Economic Review, 54, 442-454. http://dx.doi.org/10.1016/j.euroecorev.2009.08.002 